\title{
Learning in the shadows: parents' investments, family burden, and students' workload in Dhaka, Bangladesh
}

\author{
Rafsan Mahmud ${ }^{1}$ B
}

Received: 13 April 2020 / Revised: 26 October 2020 / Accepted: 26 October 2020 / Published online: 7 February 2021

(c) Education Research Institute, Seoul National University, Seoul, Korea 2021

\begin{abstract}
Privatization, marketization, investment, and competition of education have become a global phenomenon with significant implications. While research on demand and patterns of shadow education are increasingly available across the world, very little is known about the scope of parents' investments, family burden, and students' workload. This paper focuses on shadow education in Dhaka, Bangladesh. Shadow education is defined as fee-based private supplementary tutoring that replicates the official school system. The study conducted on shadow education uses an explanatory sequential mixed methods design with quantitative data from questionnaires of 354 participants, involving students and parents, and qualitative data from interviews of 24 participants, including students, parents, and teachers. The aim of this paper is to examine how parents' investments in their children's private tutoring create high expectations and competition that bring financial burden to families in a disadvantaged society. It addresses the experiences of students' workloads due to extra lessons of several subjects in a day, exam preparation pressure, and parents' and peer pressures in the desire not to lag behind. It shows how students deal with time shortages for workloads from extra lessons and deprive themselves of sports and social activities, which are part and parcel of being a mentally, emotionally, and physically healthy human being. The study draws on the theories of educational privatization, competition, investment, and capability approach, which are then associated with the research contexts of this paper.
\end{abstract}

Keywords Shadow education $\cdot$ Investment $\cdot$ Burden $\cdot$ Workload $\cdot$ Private supplementary tutoring $\cdot$ Bangladesh

\section{Introduction}

The global existence of private supplementary tutoring plays a significant role in students' learning. Private tutoring has been particularly prominent in affluent parts of East Asia, but is now found equally in low- and middle-income countries in South and Southeast Asia (Bray et al. 2020, p. 11). In Asia, Africa, Europe, and North America, private tutoring exists prominently (Bray and Lykins 2012; Entrich 2018; Hamid et al. 2009; Kwok 2001; Mahmud and Kenayathulla 2018; Silova 2010; Yung 2019). Private supplementary tutoring, which costs families' extra fees, is widely called "shadow education" because its form is different compared to mainstream schooling. The metaphor of "shadow" is also available in several studies (Bray 2009; Entrich 2015;

Rafsan Mahmud

rafsan31@gmail.com

1 Department of English, Bangladesh Open University, Gazipur 1705, Bangladesh
Mahmud 2018, 2019; Manzon and Areepattamannil 2014; Yip 2014; Yung 2020). This shadow education may consume too much of students' time and energy and lead to fatigue in school classes (Liu and Bray 2020, p. 2). Kim (2016, p. 167) notes that shadow education (hakwon) puts a heavy burden of study on students in Korea. Free time and recreational activities are necessary for students' practical lives, as they help motivate students to have learning responsibility and remove the monotony of constant learning.

Much of the education provided in Dhaka is by nongovernment institutions or partly funded government institutions, while private tutors give lessons at their residences, learners' houses, or tutorial/coaching centers. In the competitive educational system of Bangladesh, parents experience a monetary challenge, as they invest in their children's tutoring corresponding to their economic abilities. Private tutoring seems to be more client-oriented than formal schooling in the marketplace. This paper has sufficient significance on this subject because it explores families' financial burden and students' workloads/stress. This 
knowledge will reduce the research gap in Bangladeshi tutoring literature and contribute to the global literature.

Parents' investments, which may cause financial pressure, are due to high expectations for their children's academic accomplishments, as academic success is a key issue in life in the neoliberal era (Phillipson 2008). Parents' economic capacity is a major issue in educational privatization, particularly in shadow education, since it costs extra money. They invest in tutoring to reduce their children's academic weaknesses. Underprivileged students may need extra help from people outside school, but it might be challenging for lack of social and financial resources (Chiu and Chow 2010). Parents' pursuance of their children's academic development impacts students' workloads because they have school tasks as well as outof-school tutoring. Parents of high achievers also feel the need to invest in their children's education to sustain their academic qualities. In a Japanese study, Matsuoka (2015, p. 287) remarks that students with a high socioeconomic status tend to use their economic capital to purchase extra learning opportunities in the educational marketplace.

More subtle forms of vulnerability concern the academic pressure put on students. Tutors may deliberately make students feel inadequate to maintain the demand for tutoring services (Bray and Kwo 2014, p. 32). The majority of teachers provide tutoring services as a means of additional income by engaging in tutorial/coaching centers and tutoring marketing in Bangladesh. At the same time, tutored students face educational pressure, exam preparation stress, meeting their parents' expectations, and peer pressure in the hope of not falling behind. Most times, the situation creates time constraints for students that may not allow them the opportunity to participate in physical sports and social activities. It is commonly visible that Bangladeshi low-income or middle-income families, which have two or more children, need to pay for tutoring despite their financial inabilities. This study imparts insights using empirical evidence from questionnaires and interviews. It uses the city of Dhaka as a research site, where students in grade eight and grade 10 and their parents participated in questionnaires as well as students, parents, and teachers attended interviews. This paper begins with a literature review of tutoring investments and students' workloads. Then, it explains the theoretical framework, context, and methodology of the study. Finally, it illustrates the findings, analysis, discussion, and conclusions surrounding the topic. The study seeks to answer the following research questions:

To what extent do parents' investments on their children's private tutoring create high expectations and competition that bring financial burden to their families?
How does private tutoring make students' stress/workloads and time reduction that deprive them of sports and social activities?

\section{Private tutoring: investment and workload}

This paper mainly concerns educational privatization, investment, and workload involving private supplementary tutoring. In a Taiwanese study, Jheng (2015) notes that parents, especially middle-class parents, usually hold high expectations toward their children, discipline them meticulously, and spend resources on their learning. Unfortunately, this can create huge pressure for their children. She adds the opinion of an interview participant to reinforce this idea, "When I asked Chi how she feels about her parents' disciplinary styles and her learning, she said her parents have very high expectations of her and that causes a great deal of stress" (p. 6). Parents' investments for tutoring may depend on the location, educational system, labor market, socioeconomic situation, and cultural issues. Tutoring investments cause students dropout rates due to the burden on family finances. In India, a study of school dropouts in the slums of Delhi found that $25.9 \%$ of the respondents expressed their inabilities to keep up with the costs of private tutoring (Chugh 2011, p. 23). Thus, richer families can secure more tutoring compared with poorer families (Hartmann 2013; Azam 2016).

Since shadow education has become more popular, middle-income and low-income families have found themselves forced to invest in private tutoring alongside public provision (Bray and Kwo 2013). In a Hong Kong study, Yip (2014, p. 83) notes that tutoring is a huge business, yielding a large profit from the pockets of parents who are willing to pay for their children's learning. Tutoring determinants and investments can be considered at the individual, household, school, and system levels (Kwok 2001). In Korea, the total household investment on private tutoring in 2006 was estimated at \$24 billion USD (Bray 2009, p. 30). Kenayathullah (2013, p. 634) examined data from a 2004/2005 Malaysian household expenditure survey and found that $20.1 \%$ of households stated that some of their expenditures go toward private tutoring.

Parents' socioeconomic foundations may increase or decrease their investments and family burden. As private tutoring is related to family economic ability, it certainly concerns family burden, which varies from parent to parent. A 2007 survey of Bangladesh by the Campaign for Popular Education (CAMPE 2007) found that private tutoring costs were $41.9 \%$ of household expenditures for students in government schools and $29.2 \%$ for students in subsidized nongovernment schools. Here private tutoring costs constituted a significant proportion of the total education cost borne by families, which was substantially higher than the cost of any other household item (Table 1). 
Table 1 Household costs for secondary schooling, Bangladesh 2005

\begin{tabular}{|c|c|c|c|c|}
\hline \multirow[t]{2}{*}{ Expenditure Items } & \multicolumn{2}{|c|}{ Government School } & \multicolumn{2}{|c|}{$\begin{array}{l}\text { Non-government } \\
\text { School }\end{array}$} \\
\hline & Taka & $\%$ & Taka & $\%$ \\
\hline Private tutoring & 4700 & 41.9 & 2210 & 29.2 \\
\hline Books & 796 & 7.1 & 686 & 9.0 \\
\hline Stationery & 1099 & 9.8 & 992 & 13.1 \\
\hline Electricity and kerosene & 461 & 4.1 & 709 & 9.4 \\
\hline Snacks & 804 & 7.2 & 751 & 9.9 \\
\hline Health service & 591 & 5.3 & 471 & 6.2 \\
\hline Uniforms & 515 & 4.6 & 410 & 5.4 \\
\hline Transports & 833 & 7.4 & 315 & 4.2 \\
\hline Other & 1405 & 12.5 & 1030 & 13.6 \\
\hline Total & 11,204 & 100.0 & 7574 & 100.0 \\
\hline
\end{tabular}

Source CAMPE (2007, p. 51)

Parents' competitive investments and expectations relating to tutoring places a heavy workload on students. In a Hong Kong study, Kwo and Bray (2014, p. 405) found that children who spend many hours in supplementary lessons may be more tired and function less effectively in regular school lessons. Due to this sort of workload placed on them from private lessons, Korean students are depicted as children in the nineteenth century, who suffered from long hours of heavy labor (Kim 2016, p. 167). In a Taiwan and Hong Kong study, Tseng (1998, p.104) found that students had been mentally and physically suffering and had less time for sports, leisure, and visiting with friends and families because of the pressure of examinations and tutoring. Thus, it is clear that tutoring may create huge pressure for children and adolescents (Bray 2013, p. 418). Students may not get spare time to mix with friends or peers because they live under the pressures of private tutoring. For many participants, tutoring leads to exhaustion and a heavy workload. The most affected are the pupils who go straight from mainstream school to supplementary class (Bray, 2003, p. 32). In a Myanmar study, Liu and Bray (2020) note that private tutoring took much of the students' energy that they would have normally devoted to mainstream schooling. On weekdays, students commonly attended tutorial classes after school for two hours, and some also received them before school started, e.g., from 6:00 a.m. to 8:00 a.m. As one student stated, "from Monday to Friday, I return home at about 4:30 p.m., and between 8:00 p.m. and 10:30 p.m. I go to tutoring." On Saturday, I go to tutoring from 7:00 a.m. to noon and in the evening from 4:00 p.m. and 7:30 p.m. On Sunday, I go to tutoring from 8:00 p.m. and 10:30 p.m. (p. 4).

Students' socioeconomic and geographic conditions have relations with access or lack of access to tutoring. They need to gain sufficient knowledge and skills regarding cultural activities and sports, since such an age is a great time for gaining this awareness and these abilities. However, the tutoring of several subjects in a day, parents' and peer pressures for extra lessons, and competition for high scores in exams inside and outside school hours reduce students' time sufficiently so that they may not get the required time to join social functions and get physical exercise. In a study, conducted in Dhaka, Cameron (2012, p. 30) refers to the combination of private tuition and mainstream school, which clearly dominates middle-class students' lives, in his qualitative data, "I don't have time for anything other than studies. My coaching starts at 10 a.m. Then I need to go to school. I come back at 5 p.m. When I come back from school, I have to study at home. I have two private tutors back to back" (Shipon).

\section{Theoretical framework}

This study draws on the concepts of educational privatization (Belfield and Levin 2002; Levin 2001, 2010; Lubienski and Lubienski 2006), investment in education (Psacharopoulos 2006; Psacharopoulos and Patrinos 2004), and capability approach (Kuhumba 2018; Naz 2016; Sen 1983). Private supplementary tutoring is considered as a form of educational privatization, which appears to be similar to the roles of private schools. In privatization theory, competition exists between public and private providers of education (Lubienski and Lubienski 2006). Expenditures on education are treated as investments in human capital. The value of such investments is measured by the returns they yield over the lifetime of a highly educated person relative to a less educated person (Psacharopoulos 2006). Investments in education behave in a way more or less similar to investments in physical capital. In advanced industrial countries, the returns from human and physical capital tend to be equated at the margin (Psacharopoulos and Patrinos 2004). Parents' investments in education always bring high expectations of returns that create pressure on students. In a disadvantaged society, investment capacity varies from parent to parent, and at times creates financial burden for families. Privatization can be connected to neoliberal ideology and human capital on beliefs that increase from market arrangements. Private tutorial centers are usually established on assumptions about the value of market competition among schools, and the necessity to introduce commercial dynamics into education (Aurini and Davies 2005).

Investment and competition tendency exist everywhere in the privatized system. According to Sen (1983), people's ability to do things should be more for their well-being. Sen argued that development can best be explained as a process of the expansion of the capabilities of people. Sen's "capability approach" is a perspective that respects human diversity in the assessment of well-being. Well-being is about the expansion of capabilities, i.e., to improve human lives by 
increasing the range of things that a person can be and do, such as being healthy, well-nourished, knowledgeable, and participating in community life (Naz 2016, p.10). According to Sen, well-being freedom focuses on a person's capability to have various functioning trajectories and to enjoy the corresponding well-being from their achievements (Kuhumba 2018).

The pattern of investment ability does not hold the same idea. Some can invest more; some can invest less; and some cannot invest at all. This situation creates inequality and financial burden among households. The classic pattern of falling returns in regard to education by level of economic development and the level of education is maintained. The private returns to higher education are increasing; the highest returns are recorded for low-income and middle-income countries and average returns are most prominent in Latin America and the Caribbean (Psacharopoulo and Patrinos 2018). Norton (2013) remarks that learners' expectations are to receive a good return on their investment - a return that will give them access to currently unattainable resources. This concept is partially relevant with Confucian-heritage locations, where education is highly valued in accordance with social and economic ladders. This encourages many parents to invest considerably in their children's education by investing in more learning resources and paying for private tutoring services (Yung 2019).

Parents' expectations, peer pressure, and the stress of exam preparation create a heavy workload and mental strain among students. Within Sen's framework, any account of human well-being and development can be seen in the evaluative space of capabilities or functioning (Clark 2005). If parents want to invest in helping their children learn, they should be aware of their children's learning capabilities and the conditions/circumstances in their children's schools. Due to the time constraints or caretaking responsibilities involved with two/three children; parents may not keep in close contact with teachers. While a few individual tutors and tutoring centers may stress study skills and well-rounded development, cram schools in Japan, South Korea, Taiwan, China, and elsewhere focus mainly on examination skills (Bray and Lykins 2012, p. 40). Sometimes parents' tension derives from children's school homework and private tutors' homework. Parents invest with the view to solve such homework problems with the help of private tutors. In a Hong Kong study, Kwok (2001, p. 162) mentions that home tutors acted like tutees' elder family members to some extent, providing academic guidance and solving tutees' personal problems.

In the privatized system, parents are treated as customers. Neoliberal ideology (Wells 2002) is connected with the notions of privatization and investment. Educational privatization leads parents to engage in the competition and investment that create family burden. Education has some value, otherwise trillions of dollars would not be spent annually around the world on it. Both states and individuals who experience such expenditures must expect a benefit in return (Psacharopoulos 2006). The perceptions of competition and investment encourage parents to seek fee-based private tutoring for their children's educational development. Privatization of education fosters social inequality of education (Watanabe 2015). Private education providers can choose types of products and prices. Parents want to join private investment for their children's learning for future goals. In Bangladesh, the government provides some funding to most non-government schools with the intention to maintain teachers' focus on their classes, yet teachers continue to offer tutoring both inside and outside of schools. In a Cambodian study, Bray et al. (2016, p. 295) note that granting higher marks to tutored students was considered another form of indirect marketization.

\section{Context: Dhaka and Bangladesh educational systems}

This research is situated in Dhaka, the capital city of Bangladesh. To provide a description of the research setting, it is necessary to address some key features of Dhaka and Bangladesh as well as the educational system of the country. Social, educational, cultural, economic, and political aspects are primarily important. Dhaka experienced a swift growth in political, economic, educational, cultural, and sports activities after gaining its independence in 1971 from Pakistan. It has been significant as a center for gymnasiums and sports including crickets, football, and cultural functions in recent years. A 2013 survey by the Bangladesh Bureau of Educational Information and Statistics reports that the total number of secondary non-government schools was 367 and the total number of government secondary schools was 23 in Dhaka (BANBEIS 2014, p. 76). Incomes, occupations, education, and physical sport options seem to be higher in Dhaka than any other city in Bangladesh.

The educational system in Bangladesh is highly subsidized. A number of non-government educational institutions receive subsidies from the government, especially for teachers' salaries. Some private and government registered schools, mostly in urban areas, follow the two languages of the National Curriculum and Textbook Board (NCTB) curriculum: Bengali and English version, and both types of schools have the same curriculum. Teachers at schools might think that the government Monthly Pay Order (MPO) for salary purposes is not enough for their livelihood, and therefore they might be encouraged to provide tutoring for sources of extra income. Further, some schoolteachers do not have MPOs, and so they might try to earn through the provision of supplementary tutoring before or after school hours. After independence, Bangladesh inherited an educational 
system composed of a small number of elite schools and a large number of lower quality institutions. Over $98 \%$ of the secondary schools have been established by local initiatives and are managed by local school managing committees (Ahmed et al. 2006, p. 5).

Bangladesh has been gaining economic growth, along with the other countries of Asia. Peoples' ability to pay tutoring fees influences demand-determinants of supplementary tutoring. Usually socioeconomic context is associated with the learner's socioeconomic background. The private financing of secondary education is high, and much of it is directed into private educational services, such as individual tutoring, rather than funneling the resources into the schools themselves (Imam 2005). Education has four stages in Bangladesh, which includes: the primary stage (grade one to five); the secondary stage (grade six to 10); the higher secondary stage (grade 11 to 12); and then tertiary level (higher education or university studies). The gross enrollment rate in secondary education in 2013 reached $65.6 \%$, while the net enrollment rate is 59\% (BANBEIS 2014; p. 25).

The administration and management procedures are directed by practices based on tradition and custom rather than responsiveness to changing needs and conditions. Intermittent and irregular attendance is a widespread and commonly accepted practice in Bangladesh (Ahmed 2011, p. 11). As private tutoring has become a prominent source of education in Bangladesh, the government has introduced various guidelines and regulations in regard to tutoring. Among the barriers to learning, teachers have been found often to be absent and to spend relatively little time actually teaching when they are in school (Cameron 2012, p. 10).

\section{Methodology}

The study employed an explanatory sequential mixed methods design (Creswell 2012, pp. 542-543) that combined quantitative and qualitative data collected from questionnaires and individual interviews. A mixed methods research may collect quantitative and qualitative information sequentially in two or more phases. This method consists of first collecting quantitative data and then collecting qualitative data to help explain or elaborate upon the results (Creswell 2012, p. 542). The study conducted data collection in Dhaka between 2014 and 2015. The researcher used a mix of qualitative and quantitative data because using only quantitative or only qualitative information would not have been sufficient to fully address the research issue. This is because the quantitative approach provides only statistical information, while the qualitative method addresses some interviews in individual practice. Thus, one single method would not have allowed adequate description, analysis and explanation of the complexity (Bray et al. 2020, p. 27).

\section{Participants and sampling}

Opportunistic and snowball (Creswell 2012, p. 209) purposeful sampling were employed. Opportunistic sampling means a purposeful sampling undertaken after the research begins to take advantage of unfolding events that help to answer research questions. Snowball sampling is a form of purposeful sampling that typically proceeds after a study begins when the researcher asks participants to recommend other individuals to be sampled (Creswell 2012, p. 209). Dhaka was chosen for the intention of understanding the urban situation of private tutoring, including urban students, parents and teachers. First, the researcher visited three secondary schools and contacted heads or principals of schools in Dhaka, among which two gave permission for data collection. One school authority informed the researcher that they were busy and not interested. Then, the researcher visited four other schools and met the heads of those schools in Dhaka. Among the four schools, the researcher chose the two schools that were most interested. In some schools there existed more than one section/classroom for each grade, so the researcher selected the first section/classroom of each grade. Schools arranged sections/classrooms in terms of merit positions of students. The researcher took written permission of the heads/principals of sampled schools. He chose two single-gender schools and two mixed-gender schools.

The researcher chose the two grades (eight and 10) because national public examinations are held during this time, which means students are evaluated and certificates are provided by the government education boards at the end of these two grades. All the students of the first section/ classroom who were present were sampled. Parents' questionnaires were also significant because their investments and expectations played substantial roles in this study. Both students and parents supplied comprehensive information through questionnaires and interviews to answer to research questions. A sample of 354 participants, including $177 \mathrm{stu}-$ dents and their 177 parents (either father or mother), participated in filling out the questionnaires in the survey process. A sample of 24 participants, comprised eight students, eight teachers, and eight parents was selected for individual interviews. The researcher chose two students, two teachers, and two parents from each school.

A sub-sample of two students was invited to participate in the interview from all surveyed students in each school. While distributing the survey questionnaires in the classroom, the author wanted to know the willingness of students to participate in the interview. Among the willing students, the researcher chose one student from grade eight and another student from grade 10 through a lottery process (at random). Moreover, each section had a class teacher. The researcher chose two class teachers from grade eight and 
grade 10. Sampled teachers and students contacted parents through telephone and the researcher selected two parents from grade eight and grade 10 based on their willingness.

\section{Procedures and instrumentation}

The role of the gatekeeper plays a crucial role in the process of data collection. A gatekeeper is an individual who has an official or unofficial role at the research site, provides entrance to a site, helps researchers locate people, and assists in the identification of places to study (Creswell 2012, p. 211). Teachers of the sampled classes and principals of the sampled schools were the gatekeepers. Two types of structured questionnaires (student and parent questionnaires) were prepared for survey process. Questionnaire folders were distributed to sampled students in schools after a briefing in the classroom. Each folder contained one student and one parent questionnaire, as well as consent forms. Students were told to supply the parent questionnaire to respective parents and fill their student questionnaires at home. Both students and parents filled out questionnaires and returned them to the researcher on a designated date. The investigator used the same code number for each student and his/ her parent to identify and match questionnaires during data analysis. Semi-structured questions were used for individual interviews. Parents, students, and teachers expressed their attitudes, expectations, and perceptions. All interviews were audio-recorded, and each interview took 30-40 min. Most interviews were conducted in vacant classrooms, common rooms, or libraries in the schools on the basis of suitability and availability.

\section{Data analysis}

The analysis was a mix of quantitative and qualitative data. Descriptive statistics were used in the quantitative data analysis using Statistical Package for the Social Sciences (SPSS) software. A coding process was employed in the qualitative data analysis. Individual interviews were conducted in Bengali language. These interview data were transcribed into Bengali immediately at the end of the interview process. The analysis of data followed several stages to make sense of the text in relation to the research questions. The researcher followed the six steps of Creswell's (2012, pp. 236-262) data analysis procedure and coding process. He prepared and organized the data for analysis and also transcribed the data in the process. The next step was to examine the data and code it. This involved reading through the database and then employing the steps involved in coding. These steps were taken to identify text segments and then to assign code labels to the segments based on the meaning. The codes were also grouped to form broader themes that emerged as key findings (Creswell 2012; p. 261).

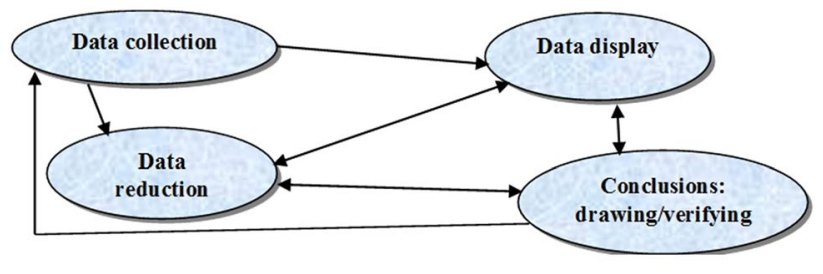

Source: Miles \& Huberman, 1994; p. 12.

Fig. 1 Components of data analysis: interactive model. Source, Miles and Huberman (1994 p. 12)

Codes are tags or labels for assigning units of meaning and these are usually attached to chunks of varying sizewords, phrases, sentences, or whole paragraphs connected or unconnected to a specific setting (Miles and Huberman 1994, p. 56). The researcher used various colors and tags for categorizing different chunks to find out answers to the research questions. He wrote various points and organized different sections to represent the data including various themes to form a general conclusion. Miles and Huberman (1994, pp. 10-12) define analysis as consisting of three concurrent flows of activity: data reduction, data display, and conclusion drawing/verification. They presented an interactive model (see Fig. 1) which was employed in the current study. The three types of analysis activities and the activity of data collection shaped an interactive cyclic procedure.

Data reduction refers to the process of selecting, focusing, simplifying, abstracting, and transforming the data. Data display means an organized and compressed assembly of information that allows for the drawing of conclusions. The third stream of analysis, conclusion drawing/verification is self-explanatory (Miles and Huberman 1994, pp. 10-11).

\section{Findings and analysis}

This study attempted to identify ways through which answers to research questions could be discovered by employing a mix of quantitative and qualitative information. Mixed methods can address complexities in social reality, obtain more comprehensive description of participants' voices, and increase the strength of understanding (Swain 2017). Qualitative data provided participants' perceptions and elaborated upon the quantitative findings, uncovering parents' investment burdens and the workload weight of studies through tutoring. The researcher tested a pilot study during May-June 2014. In the pilot study, he conducted the student survey in classrooms of schools and found some complexities. For example, some students filled out questionnaires by reading swiftly or without reading them very well. Then, the researcher revised the survey questionnaires and interview questions for the development of the final study. In the 
Table 2 Description of participants

\begin{tabular}{lllccc}
\hline Schools in Dhaka & $\begin{array}{l}\text { 8th Grade } \\
\text { students }\end{array}$ & $\begin{array}{l}\text { 10th Grade } \\
\text { students }\end{array}$ & $\begin{array}{l}\text { Total student survey } \\
\text { participants }\end{array}$ & $\begin{array}{l}\text { Total parent survey } \\
\text { participants }\end{array}$ & Total interview participants \\
\hline School 1 & 25 & 24 & 49 & 49 & 2 students +2 parents +2 teachers $=6$ \\
School 2 & 17 & 15 & 32 & 32 & 2 students +2 parents +2 teachers $=6$ \\
School 3 & 21 & 20 & 41 & 41 & 2 students +2 parents +2 teachers $=6$ \\
School 4 & 27 & 28 & 55 & 55 & 2 students +2 parents +2 teachers $=6$ \\
Total & 90 & 87 & 177 & 177 & 24 \\
\hline
\end{tabular}

final study, students completed the survey at their respective homes. The investigator believed that parents are knowledgeable of family economic and their social conditions that relate to family burden and difficulties of access to tutoring, and that students might be more apt to express their stress or experiences of a heavy workload without hesitation. Table 2 shows the description of participants that provided information through questionnaires and interviews.*

\section{Investment and burden}

Questionnaire data showed that private tutoring was widespread. In accordance with the survey, $84.4 \%$ of the 8 th grade students and $85.1 \%$ of the 10 th grade students received private tutoring. Table 3 shows parents' views on how their investments in private tutoring for their children's educational development became a burden for their families. More than one-third (34.5\%) of parents provided views that they faced a light burden for their investments in their children's tutoring. Private supplementary tutoring was, to some extent, a financial burden to a large number of families. In some cases, teachers' indirect marketing in classes inspired children to seek tutoring. Further, parents continued investment for children's tutoring to follow the local culture of supplementary tutoring despite their economic crises. A similar result was found in a Korean study, in which Kim (2016, p. 165) noted that many parents spent the largest portion of their incomes on their children's private tutoring. A few parents believe that their children can acquire a higher performance when they invest more money in tutoring. Tutoring is considered as a way of advancing,

Table 3 Parents' views on family burden for their investments/costs of children's private tutoring $(N=177)$

\begin{tabular}{lll}
\hline Family financial burden & Frequency & Percentage \\
\hline Heavy burden & 43 & 24.3 \\
A moderate burden & 41 & 23.2 \\
A light burden & 61 & 34.5 \\
Not at all a burden & 23 & 13.0 \\
No opinion & 9 & 05.1 \\
\hline
\end{tabular}

not just supplementing of formal schooling. Nearly a quarter $(23.2 \%)$ of parents indicated that they faced a moderate burden due to their investments in their children's tutoring. Some parents invest in tutoring with the presumption that their future (particularly at the old age) depends on their children's educational success.

Parents believe that their children can achieve higher grades in school when they invest more for tutoring. At times, neighboring families motivated other parents to invest in children's out-of-school lessons. As teachers could not finish the course curriculum all of the time, parents invested in tutoring, considering it as a convenient tool. One parent stated, "I face challenges to maintain my family with minimum income, yet I do not discourage my daughter for tutoring. I want a bright future in my daughter's life." Around a quarter (24.3\%) of parents indicated that they faced a heavy burden due to the investment in their children's tutoring (see Table 3). Several parents experienced financial heavy burden, but did not share those difficulties with other people or their children. One parent was not able to visit his rural home at a distant location for shortage of money since he needed to pay three children's tutoring fees.

As indicated by teacher interviewees, some parents tried to avoid and did not like tutoring but invested in them regardless, due to regional and school culture. One student referred to his parent's financial trouble. He stated, "My father is a day-laborer. His income is limited. Though he does not want my tutoring, I continue it for success in examination and peer's motivation." Children could share their learning difficulties easily with private tutors in tutoring sessions, and it was difficult with teachers in schools as well. As Dawson (2010, p. 14) noted in his study regarding Japan, South Korea, and Cambodia, private tutoring in each nation can be used to reveal the inadequacies of the formal educational system in meeting the ideal of equal opportunity to education.

\section{Workload and deprivation}

Data show the rise of students' work pressure through supplementary lessons. Table 4 shows students' opinions on 
how private supplementary lessons raised workload and reduced time for necessary activities, including physical exercise and social activities. A major portion $(36.2 \%)$ of students provided their views that supplementary tutoring created a heavier workload and pressure that reduced time for sports and social functions. The concepts of educational privatization, investment, competition, tutoring on several subjects in a day, and parents' high expectations caused a huge stress of study on students. In interviews, students indicated that their parents' investments on tutoring put pressure on them. As Bray et al. (2020, p. 44) noted in a Myanmar study, students certainly possess study load. Most students have their tutorial classes after the school classes, but a few undertook them before the school class, commencing at 6:00 a.m. Students should experience various things in practical life. So, their learning should not only be through books and school.

Parents invested and pressured children at times with high expectation for achieving good scores on school examinations. Some of them scolded students after the publication of examination results. One student stated, "My parents become angry when I show my exam grades. My father talks to my private tutors about the status of test results. He recommends me to be attentive to tutorial classes." Each year, private tutors were changed. Parents brought new private tutors, as they assumed new tutors would provide better performance. Private tutors offer attractive packages of model tests at tutorial centers reproducing sample questions as per school exam question patterns, and parents think of these as investment opportunities for children's educational development. That is why students carry a huge workload or experience heavy pressure at times. Pedagogical and curricular practices in the private tutoring systems have functioned to increase anxiety and insecurity in regard to the formal education system with the purpose of expanding the market (Dawson (2010, p. 14).

Around one-third (28.9\%) of students indicated that they faced a moderate workload and amount of pressure for tutoring which reduced the duration for physical exercise and social activities (see Table 4). As noted in interview data, parents eagerly invest for children's science practical marks.

Table 4 Students' views on the rise of workload, pressure, time reduction and deprivation of sports and social activities $(N=177)$

\begin{tabular}{lcl}
\hline $\begin{array}{l}\text { Rise of workload and depriva- } \\
\text { tion }\end{array}$ & Frequency & Percentage \\
\hline A lot & 54 & 36.2 \\
A moderate amount & 43 & 28.9 \\
A light & 32 & 21.5 \\
Not at all & 8 & 05.4 \\
No opinion & 12 & 08.1 \\
\hline
\end{tabular}

They think children will receive good marks in science practical tests if they take private tuition from science teachers at the schools. One student said, "I feel a tension in science practical exam room if I do not receive private tuition from the science teacher of our school". Some parents invested higher and chose standard coaching centers where students were categorized into different groups based on the learner's merit and individual tests. Students experienced mental stress in the process of such tutoring sessions.

The majority of parents referred to strong academic competition which inspired them to invest in private tutoring for their children's future goals. Students felt pressure by peers or neighboring students who had competitive viewpoints involving extra lessons. One student indicated, "Much competition exists among peers. Peers and neighboring students motivate us to participate in tutoring. Indeed, participation in tutoring is a mental stress because I do not find enough time to do other things." Parents invested in the hopes that their children might not fall behind in the contest with their peers with supplementary lessons. School homework and private tutors' homework at the same time increased learners' workload and mental stress.

As indicated by interviewees, parents invested in tutoring as an instrument to enhance their children's learning motivation. As Bray and Kwok (2003, p. 615) noted in their Hong Kong study, many students received tutoring to meet parental obligations. Less than a quarter (21.5\%) of students mentioned that tutoring reduced their workload or pressure. At the same time, only $05.4 \%$ of students indicated that tutoring did not bring any additional workload or pressure. In interviews, a small number of students stated that they did not feel too overloaded or pressured, while a few noted that they did not feel stress at all. Several teachers referred strongly to a barricade of students' mental development in daily life. As learners are busy with private tutoring in several subjects regularly, they are not commonly able to attend religious festivals or visit their relatives' homes.

\section{Discussion and conclusions}

This paper focused on parents' investments and the burden that placed on their families, which is a contradictory attitude toward private tutoring. It is evident that all parents who invest in tutoring do not experience burden as reported by data. It illustrates another point concerning the workload of tutored students who are responsible for formal schooling inside schools and at the same day responsible for private supplementary lessons outside school hours. The study has informed the paradigm of the relationship between investment and burden, which is commonly visible in a disadvantaged society, particularly in Bangladesh. Based on their investments, parents nurture high ambition and expectations 
toward their children's education through private tutoring. Given that all parents do not have equal economic capacities, they attempt to receive benefits from children's supplementary lessons through their investments. This situation sometimes creates a burden for the family. By considering participants' data, this paper has revealed parents' investments and their high expectations for children's educational development, which creates more of a workload for students outside school hours and reduced their time for essential physical exercise and social activities in daily life.

The theoretical framework matched the themes, some of which illustrated educational privatization, competition, investment, and capability approach. It is clear that private investment on tutoring brings burden among families, while workload arises among students due to their parents' high expectations and pressure for better exam scores. Individual capacity could be fostered in society, but is independent of the social context, e.g., inherited physical and mental qualities. Inherited physical and mental qualities have their own effects on capabilities (Jackson 2005). Returns from schooling are a useful indicator of the productivity of education and incentive for individuals to invest in their own capital (Psacharopoulos and Patrinos 2004). Educational privatization encourages rearrangement of government (public) and market (private) practices through educational efficiency and parental choice (Belfield and Levin 2002; Levin 2001, 2010; Murphy 1996; Zhan 2014). Usually, parents invest in private tutoring for their children's education, while exceptions are found in some countries. For example, out-ofschool programs are provided by schools and invested by the government in South Korea (Zhan 2014). The efficiency of the school system improves by reaching the unreached and increasing access to education or developing learning outcomes through fostering competition (Watanabe 2015). Tutoring provides alternative functions of academic lessons and creates competition, which enhances social inequality and financial burden between poor and rich parents (Bray 2009; Bray and Lykins 2012; Entrich 2018; Kim 2016; Zhang 2013).

If learning is a major element of success and achievement, parents' investments may help children with an impression of progress and outcome. Tutoring may be part of a phenomenon in which parents feel both social pressure and cohesion (Bray 2009; Heyneman 2011). Variations of learning needs are perceived by students. It is implicit that parents may meet these learning needs by investing in outof-school lessons. But parents' economic conditions are different, dependent upon their incomes and social positions. Parents that have more than one child experienced burden to maintain their children's tutoring expenditures in most cases. Many parents wanted to develop their children's education through tutoring, although their economic limitations did not provide access to tutoring all the time. This paper echoes similar conceptualization by Dang (2007) in his Vietnam study, in which the quality of a child's schooling is represented by a household investment in tutoring.

Behind the façade of educational privatization, neoliberalism, investment, and the capability approach, the feecharging tutoring phenomenon creates a stratification based on parents' economic conditions in a disadvantaged society. Parent interviewees referred repeatedly to unequal financial backgrounds that impacted access or non-access to tutoring

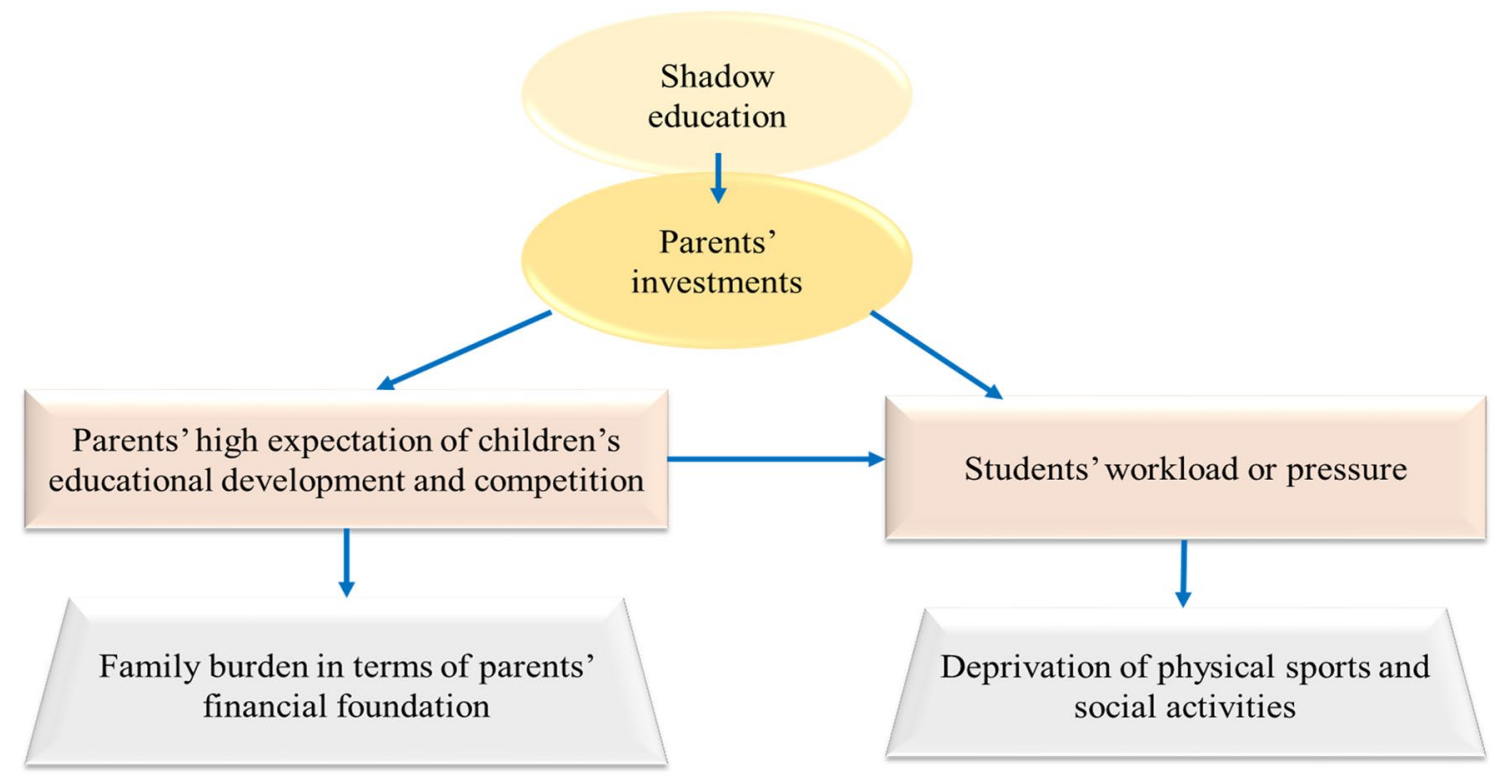

Fig. 2 Parents' investments, family burden, and students' workload in private tutoring 
between parents holding financial burden and parents without financial burden. The situation was noted in various studies (Kim 2016; Kobakhidze 2018; Matsuoka 2015; Silova 2010) in which parents' investment determined disparity of access to tutoring between high-income and low-income groups. Tutoring might be a remedial strategy for low-performing pupils, but it raises a debate about parents' impressions concerning family financial burden.

This paper aimed at answering questions of workload and pressure. Competition of tutoring sessions for exam preparation and parents' goals consumes sufficient time that creates students' mental stress in daily life. As Kim (2016, p. 166) argues in his Korean study, shadow education (hakwon) can create rivalry between peers, increase anxiety and tension about academic performance, and decrease the time for a hobby or free time. Data indicate that exam preparation pressure, parents' high expectation, private tutor's homework, and peer pressure obviously make the workload in relation to studies heavier for students, while a student life should be a time for learning various kinds of lessons and principles as well. These pressures reduce their time and bring about obstacles for participating in physical sports and social activities.

As indicated in Fig. 2, shadow education is concerned with parents' investments and their high expectations that impact their family financial conditions. These create family burden to some extent, and increase students' workload or mental stress, depriving them of sports, recreation, and social functions. As mentioned above, the lack of recreation/ social activities and pressure in two/three tutoring sessions on various subjects per day do not suit a learner's improvement or mental development in education. In an Asian study, Bray and Kwo (2014, p. 30) note that excessive tutoring can damage children's physical and mental health, and sometimes leads to inefficiencies in regular schooling since students are tired in the daytime.

Limitations of the paper arise from its focus on just four schools in Dhaka and from the sample that does not represent the whole of Bangladesh's student population. Another weakness in the study is that students' stress or workloads might differ based on the nature of private tutoring, frequency, length of tutoring, interest of students for academic subjects, among others. The researcher did not collect all the information on these factors from participants. Further research may point to policy attention, including weaknesses in the school system, competition between lowincome and solvent groups, and the roles of students and parents on shadow education on a larger scale. The government may pay particular attention to matters of policy analysis for shadow schooling, including nation-building and well-adjusted development through sports and academic attainment.
The implications of the study concern the understanding of policymakers about parents' investments, expectations, family burden, and students' workloads. The existence and expansion of investments and expectations in tutoring are always aligned with the workload and pressure placed upon students. Students sought tutoring since it was normal to do so and due to pressures from teachers, peers, and others. Besides, students think that it's better to avoid the risks that might arise from not doing so (Liu and Bray 2020, p. 6). As Chan and Bray (2014, p. 365) noted in a Hong Kong study, schooling was commonly described as fee-free and equitable at an official level; yet behind this façade, households could find themselves forced to invest in shadow education. Private tutoring is going to be embedded in the culture. Therefore, policymakers need to take initiatives to reduce the amount of shadow education that students receive, rather than waiting until the problem becomes deeply rooted. Though the current study has focused only on Dhaka, it is reasonable to assume that its vital themes have relevance throughout Bangladesh. Findings of the study might be useful to policymakers and academics, providing a potential value in national and international domains.

\section{References}

Ahmed, M. (2011). Education in Bangladesh: Anatomy of recent progress. In M. Ahmed (Ed.), Education in Bangladesh: Overcoming hurdles to equity with quality. Dhaka: Brac University Press.

Ahmed, M., Nath, S. R., Hossain, A., \& Kalam, M. D. (2006). The state of secondary education: Progress and challenges. (Education Watch 2005 report). Dhaka, Bangladesh: Campaign for Popular Education (CAMPE).

Aurini, J., \& Davies, S. (2005). Choice without markets: Homeschooling in the context of private education. British Journal of Sociology of Education, 26(4), 461-474.

Azam, M. (2016). Private tutoring: Evidence from India. Review of Development Economics, 20(4), 739-761.

Bangladesh Bureau of Educational Information and Statistics (BANBEIS). (2014). Bangladesh education statistics 2013. Dhaka, Bangladesh: BANBEIS.

Belfield, C. R., \& Levin, M. H. (2002). Education privatization: Causes, consequences and planning implications. Paris: UNESCO International Institute for Educational Planning (IIEP).

Bray, M. (2003). Adverse effects of private supplementary tutoring: Dimensions, implications, and government responses. Paris: UNESCO International Institute for Educational Planning.

Bray, M. (2009). Confronting the shadow education system: What government policies for what private tutoring? Paris: International Institute for Educational Planning (IIEP), UNESCO.

Bray, M. (2013). Shadow education: Comparative perspectives on the expansion and implications of private supplementary tutoring. Procedia - Social and Behavioral Sciences, 77, 412-420.

Bray, M., \& Kwo, O. (2013). Behind the façade of fee-free education: Shadow education and its implications for social justice. Oxford Review of Education, 39(4), 480-497.

Bray, M., \& Kwo, O. (2014). Regulating private tutoring for public good: Policy options for supplementary education in Asia. Hong 
Kong: Comparative Education Research Centre, University of Hong Kong, and Bangkok: UNESCO.

Bray, M., \& Kwok, P. (2003). Demand for private supplementary tutoring: Conceptual considerations and socio-economic patterns in Hong Kong. Economics of Education Review, 22(6), 611-620.

Bray, M. \& Lykins, C. (2012). Shadow education: Private supplementary tutoring and its implications for policy makers in Asia. Mandaluyong City, Philippines: Asian Development Bank and Hong Kong: Comparative Education Research Centre, The University of Hong Kong.

Bray, M., Kobakhidze, M. N., Liu, J., \& Zhang, W. (2016). The internal dynamics of privatized public education: Fee-charging supplementary tutoring provided by teachers in Cambodia. International Journal of Educational Development, 49, 291-299.

Bray, M., Kobakhidze, M. N., \& Kwo, O. (2020). Shadow education in Myanmar: Private supplementary tutoring and its policy implications. Paris: UNESCO, and Hong Kong: Comparative Education Research Centre, The University of Hong Kong.

Cameron, S. (2012). The urban drive: Poor and middle class children's experiences of school in Dhaka, Bangladesh. Working paper 2012-08. Florence: UNICEF Office of Research.

Campaign for Popular Education (CAMPE). (2007). Financing primary and secondary education in Bangladesh. (Education Watch 2006 report). Dhaka, Bangladesh: CAMPE.

Chan, C., \& Bray, M. (2014). Marketized private tutoring as a supplement to regular schooling: Liberal Studies and the shadow sector in Hong Kong secondary education. Journal of Curriculum Studies, 46(3), 361-388.

Chiu, M. M., \& Chow, B. W. Y. (2010). Culture, motivation, and reading achievement: High school students in 41 countries. Learning and Individual Differences, 20(6), 579-592. https://doi. org/10.1016/j.lindif.2010.03.007

Chugh, S. (2011). Dropout in secondary education: A study of children living in slums of Delhi. New Delhi: National University of Educational Planning and Administration.

Clark, D. A. (2005). Sen's capability approach and the many spaces of human well-being. Journal of Development Studies, 41, 13391368. https://doi.org/10.1080/00220380500186853

Creswell, J. W. (2012). Educational research: Planning, conducting, and evaluating quantitative and qualitative research (4th ed.). Boston: Pearson

Dang, H. (2007). The determinants and impact of private tutoring classes in Vietnam. PhD dissertation. USA: The University of Minnesota.

Dawson, W. (2010). Private tutoring and mass schooling in East Asia: Reflections of inequality in Japan, South Korea, and Cambodia. Asia Pacific Education Review, 11(1), 14-24.

Entrich, S. R. (2015). The decision for shadow education in Japan: Students' choice or parents' pressure? Social Science Japan Journal, 18(2), 193-216.

Entrich, S. R. (2018). Shadow education and social inequalities in Japan: Evolving patterns and conceptual implications. Dordrecht: Springer.

Hamid, M. O., Sussex, R., \& Khan, A. (2009). Private tutoring in English for secondary school students in Bangladesh. TESOL Quarterly, 43(2), 285-287.

Hartmann, S. (2013). Education 'home delivery' in Egypt: Private tutoring and social stratification. In M. Bray, A. E. Mazawi, \& R. G. Sultana (Eds.), Private tutoring across the Mediterranean: Power dynamics and implications for learning and equity (pp. 57-75). Rotterdam: Sense Publishers.

Heyneman, S. P. (2011). Private tutoring and social cohesion. Peabody Journal of Education, 86(2), 183-188.
Imam, S. R. (2005). English as a global language and the question of nation-building education in Bangladesh. Comparative Education, 41(4), 471-486.

Jackson, W. A. (2005). Capabilities, culture and social structure. Review of Social Economy, 63, 101-124. https://doi.org/10.1080/00346 760500048048

Jheng, Y. J. (2015). The influence of private tutoring on middle-class students' use of in-class time in formal schools in Taiwan. International Journal of Educational Development, 40, 1-8.

Kuhumba, S. (2018). Amartya Sen's capability approach as theoretical foundation of human development. Journal of Sociology and Development, 1(1), 127-145.

Kenayathulla, H. B. (2013). Household expenditures on private tutoring: Emerging evidence from Malaysia. Asia Pacific Education Review, 24(2), 629-644.

Kim, Y. C. (2016). Shadow education and the curriculum and culture of schooling in South Korea. New York: Palgrave Macmillan.

Kobakhidze, M. N. (2018). Teachers as tutors: Shadow education market dynamics in Georgia, Comparative Education Research Centre, The University of Hong Kong, and Dordrecht: Springer.

Kwo, O., \& Bray, M. (2014). Understanding the nexus between mainstream schooling and private supplementary tutoring: Patterns and voices of Hong Kong secondary students. Asia Pacific Journal of Education, 34(4), 403-416.

Kwok, P. (2001). A multi-level social analysis of demand for private supplementary tutoring at secondary level in Hong Kong. $\mathrm{PhD}$ dissertation. Hong Kong: The University of Hong Kong.

Levin, H. M. (2010). Issues in educational privatization. In H. F. Ladd \& E. B. Fiske (Eds.), Handbook of research in education finance and policy (pp. 391-401). New York: Routledge Taylor and Francis Group.

Levin, H. M. (Ed.). (2001). Privatizing education: Can the market place deliver choice, efficiency, equity and social cohesion? Oxford: Westview Press.

Liu, J., \& Bray, M. (2020). Private subtractory tutoring: The negative impact of shadow education on public schooling in Myanmar. International Journal of Educational Development, 76, 1-8. https ://doi.org/10.1016/j.ijedudev.2020.102213

Lubienski, C. \& Lubienski, S. T. (2006). Charter, private, public schools and academic achievement: New evidence NAEP mathematics data (Vol. 16). New York: National Center for the Study of Privatization in Education, Teachers College, Columbia University.

Mahmud, R. (2018). Shadow schooling in South Asia: Contexts, forms and characteristics of private supplementary tutoring in English at secondary level in rural Bangladesh. In K. J. Kennedy \& J. C. K. Lee (Eds.), Routledge international handbook of schools and schooling in Asia (pp. 343-354). Oxon and New York: Routledge Taylor and Francis.

Mahmud, R. (2019). Mixed implications of private supplementary tutoring for students' learning: Urban and rural disparities in Bangladesh. International Journal of Comparative Education and Development, 21(1), 61-75.

Mahmud, R., \& Kenayathulla, H. B. (2018). Shadow education: Patterns and scale for private supplementary tutoring in English in secondary education at urban Dhaka in Bangladesh. Compare: A Journal of Comparative and International Education, 48(5), 702-716.

Manzon, M., \& Areepattamannil, S. (2014). Shadow education: Mapping the global discourse. Asia Pacific Journal of Education, 34(4), 389-402.

Matsuoka, R. (2015). School socioeconomic compositional effect on shadow education participation: Evidence from Japan. British Journal of Sociology of Education, 36(2), 270-290. 
Miles, M. B., \& Huberman, A. M. (1994). Qualitative data analysis: An expanded sourcebook (2nd ed.). Thousand Oaks, London, New Delhi: Sage.

Murphy, J. (1996). The privatization of schooling: Problems and possibilities. Thousand Oaks, CA: Corwin Press.

Naz, F. (2016). Understanding human well-being: How could Sen's capability approach contribute? Forum for Social Economics. https://doi.org/10.1080/07360932.2016.1222947

Norton, B. (2013). Identity and language learning: Extending the conversation (2nd ed.). Bristol: Multilingual Matters.

Phillipson, R. (2008). The linguistic imperialism of Neo-liberal Empire. Critical Inquiry in Language Studies, 5(1), 1-43. https ://doi.org/10.1080/15427580701696886

Psacharopoulo, G. (2006). The value of investment in education: Theory, evidence and policy. Journal of Education Finance, 32(2), 113-136.

Psacharopoulo, G., \& Patrinos, H. A. (2004). Returns to investment in education: A further update. Education Economics, 12(2), 111-133.

Psacharopoulo, G., \& Patrinos, H. A. (2018). Returns to investment in education: A decennial review of global literature. Education Economics, 26(5), 445-458.

Sen, A. (1983). Development: Which way now? The Economic Journal, 93, 745-776.

Silova, I. (2010). Private tutoring in Eastern Europe and Central Asia: Policy choices and implications. Compare, 40(3), 327-344.

Swain, J. (Ed.). (2017). Designing research in education: Concepts and methodologies. Thousand Oaks: SAGE.

Tseng, L. (1998). Private supplementary tutoring at the senior secondary level in Taiwan and Hong Kong. MEd dissertation. Hong Kong: The University of Hong Kong.
Watanabe, M. (2015). The privatization of education in developing countries: Evidence and policy implications. Working papers on education policy 2, Section of Education Policy, UNESCO Education Sector.

Wells, A. S. (2002). Why public policy fails to live up to the potential of charter school reform: An introduction. In A. S. Wells (Ed.), Where charter school policy fails: The problems of accountability and equity (pp. 1-28). New York: Teachers College Press.

Yip, K. W. (2014). Shadow education in Hong Kong: Typology and educational functions of private supplementary tutoring. MEd dissertation, Hong Kong: The University of Hong Kong.

Yung, K. W. H. (2019). Investing in English private tutoring to move socially upward: A narrative inquiry of an underprivileged student in Hong Kong. Journal of Multilingual and Multicultural Development. https://doi.org/10.1080/01434632.2019.1660667

Yung, K. W. H. (2020). Comparing the effectiveness of cram school tutors and school teachers: A critical analysis of students' perceptions. International Journal of Educational Development, 72, 1-10. https://doi.org/10.1016/j.ijedudev.2019.102141

Zhan, S. (2014). The private tutoring industry in Taiwan: Government policies and their implementation. Asia Pacific Journal of Education, 34(4), 492-504.

Zhang, W. (2013). Private supplementary tutoring received by Form 3 students in Chongqing, China: Determinants of demand, and policy implications. $\mathrm{PhD}$ dissertation. Hong Kong: The University of Hong Kong.

Publisher's Note Springer Nature remains neutral with regard to jurisdictional claims in published maps and institutional affiliations. 